Article

\title{
Combined Application of Rhizosphere Bacteria with Endophytic Bacteria Suppresses Root Diseases and Increases Productivity of Black Pepper (Piper nigrum L.)
}

\author{
Sy Dinh Nguyen ${ }^{1, *}$, Thi Huyen Trang Trinh ${ }^{1}$, Trung Dzung Tran ${ }^{1}$, Tinh Van Nguyen ${ }^{1}$, Hoang Van Chuyen ${ }^{2}$, \\ Van Anh $\mathrm{Ngo}^{3}$ and Anh Dzung Nguyen ${ }^{3}$ (i) \\ 1 Faculty of Natural Science and Technology, Tay Nguyen University, 567 Le Duan Street., Buon Ma Thuot, \\ Dak Lak 630000, Vietnam; tthtrang@ttn.edu.vn (T.H.T.T.); ttdung@ttn.edu.vn (T.D.T.); \\ nvtinh@ttn.edu.vn (T.V.N.) \\ 2 Faculty of Agriculture \& Forestry, Tay Nguyen University, 567 Le Duan Street., Buon Ma Thuot, \\ Dak Lak 630000, Vietnam; hvchuyen@ttn.edu.vn \\ 3 Institute of Biotechnology and Environment, Tay Nguyen University, 567 Le Duan Street., Buon Ma Thuot, \\ Dak Lak 630000, Vietnam; ngovananh_09@yahoo.com (V.A.N.); nadzung@ttn.edu.vn (A.D.N.) \\ * Correspondence: ndsy@ttn.edu.vn; Tel.: +84-623-853-276 or +84-961-367-958
}

check for updates

Citation: Nguyen, S.D.; Trinh, T.H.T.; Tran, T.D.; Nguyen, T.V.; Chuyen, H.V.; Ngo, V.A.; Nguyen, A.D. Combined Application of Rhizosphere Bacteria with Endophytic Bacteria Suppresses Root Diseases and Increases Productivity of Black Pepper (Piper nigrum L.). Agriculture 2021, 11, 15. https:// doi.org/10.3390/agriculture11010015

Received: 10 November 2020 Accepted: 23 December 2020 Published: 28 December 2020

Publisher's Note: MDPI stays neutral with regard to jurisdictional claims in published maps and institutional affiliations.

Copyright: () 2020 by the authors. Licensee MDPI, Basel, Switzerland. This article is an open access article distributed under the terms and conditions of the Creative Commons Attribution (CC BY) license (https: / / creativecommons.org / licenses/by/4.0/).

\begin{abstract}
Black pepper (Piper nigrum L.) is one of the most important crops and global demand continues to increase, giving it a high export value. However, black pepper cultivation has been seriously affected by a number of pathogenic diseases. Among them, "quick wilt" caused by Phytophthora sp., "slow decline" caused by Fusarium sp., and root-knot nematode Meloidogyne sp. have a serious negative effect on black pepper growth and productivity. There have been different chemical and biological methods applied to control these diseases, but their effectiveness has been limited. The aim of this research was to evaluate different combinations of rhizosphere bacteria and endophytic bacteria isolated from black pepper farms in the Central Highland of Vietnam for their ability to suppress pathogens and promote black pepper growth and yield. Formula 6, containing the strains Bacillus velezensis KN12, Bacillus amyloliquefaciens DL1, Bacillus velezensis DS29, Bacillus subtilis BH15, Bacillus subtilis V1.21 and Bacillus cereus CS30 exhibited the largest effect against Phytophthora and Fusarium in the soil and in the roots of black pepper. These bio-products also increased chlorophyll a and $\mathrm{b}$ contents, which led to a 1.5-fold increase of the photosynthetic intensity than the control formula and a $4.5 \%$ increase in the peppercorn yield (3.45 vs. 3.30 tons per hectare for the control). Our results suggest that the application of rhizosphere and endophytic bacteria is a promising method for disease control and growth-promotion of black pepper.
\end{abstract}

Keywords: bio-products; black pepper; rhizosphere bacteria; endophytic bacteria; Phytophthora; Fusarium

\section{Introduction}

Black pepper (Piper nigrum L.) is a perennial woody vine in the Piperaceae family which is mainly cultivated in tropical and sub-tropical countries such as India, Indonesia, Malaysia, Brazil, Thailand, Sri Lanka, China, and Vietnam [1]. The fruits of black pepper, known as peppercorns, have been used for food flavoring, perfumery, and enhancing the bioavailability of companion drugs [2]. Peppercorns and black pepper oil have also been reported to have beneficial antioxidant, anticancer, antipyretic, anti-inflammatory, and anti-microbial activities [3]. Vietnam is the world's largest cultivation area and exporter of peppercorns with approximately $40 \%$ of the world's crop [4]. In 2019, Vietnam had approximately 100,000 hectares of black pepper which produced 247,000 tons of peppercorns valued at USD 571 million.

Recently, black pepper crops in the Central Highland of Vietnam have faced a number of diseases such as quick wilt, slow decline, anthracnose, stunt disease, phyllody disease, 
basal wilt, leaf rot, and blight. Among them, "quick wilt" disease (foot rot), which is caused by Phytophthora tropicalis and Phytophthora capsici [5], and "slow decline" disease, which is caused by Fusarium spp., and the root-knot nematode Meloidogyne spp. [6,7], are the most serious diseases that damage the growth and productivity of black pepper crops $[8,9]$. The utilization of chemical fungicides and nematodecides are the most common approaches for disease management of black pepper in Vietnam. However, this method is harmful to the farmers and the environment due to the potential pollution and lack of biosafety indicators. Thus, controlling pathogenic diseases is one of the biggest challenges facing black pepper production in Vietnam. The literature on black pepper cultivation suggests that disease management has to apply to all stages of the life-cycle, including the selection of resistant varieties, planting of disease-free seeds, cultivation methods and biological measures $[10,11]$. Besides traditional chemical methods, recent studies have used soil microorganisms as a biological approach to control plant diseases. It was reported that the use of rhizosphere bacteria and endophytic bacteria are effective for disease management and plant growth promotion, and are also environmentally friendly for agricultural products including black pepper $[3,10,11]$. Moreover, the utilization of local microorganisms combined with agricultural management practices positively affected soil nematode community and soil nitrogen cycling $[12,13]$ or inhibited the growth of pathogenic bacteria such as Staphylococcus aureus and E. coli $[14,15]$. These research results suggest that the application of microorganism may be a promising method for disease control and the sustainable production of black pepper in the Central Highlands of Vietnam.

Slow decline disease (root-knot nematode), mainly caused by Fusarium spp. and Meloidogyne spp., is considered a serious problem as it impacts over 5500 plant species worldwide $[7,16]$. Meloidogyne spp. triggers disease in black pepper and causes yellowing, stunted growth, drying in the margins and tips of leaves, wilting and root-knot, followed by the rotting of roots which leads to the death of the plant [17-19]. Slow decline disease has been controlled using biological methods involving microbes to inhibit nematodes based on their products such as enzymes, volatiles, and other natural compounds [20-23]. The application of endophytic bacteria against nematodes promoted plant growth and attracted attention from researchers [24-28]. The results showed that these selected endophytic bacterial strains may be candidates for the biological control of Meloidogyne spp. and promotion of growth in black pepper.

Quick wilt disease is mainly caused by Phytophthora sp., an oomycete plant pathogen $[29,30]$. Phytophthora is one of the pathogenic fungi that seriously affect the growth and development of tropical agricultural crops, growth and development, especially black pepper $[10,30]$.

Root rot caused by Phytophthora in black pepper has been reported as one of the most serious diseases reducing the production of black pepper in Vietnam and other Asian countries [8,9]. To control Phytophthora in black pepper, the utilization of chemical pesticides is currently the most commonly-used method, but this may cause toxic pollution and poses risks to farmers and ecosystems. Due to the disadvantages associated with using chemicals, more environmentally friendly methods, such as using resistant varieties, advanced agricultural practices and biocides, have been studied for controlling the disease [31-33]. Biocontrol using bio-products containing bacteria strains isolated from rhizosphere bacteria and endophytic bacteria has been recommended as an effective solution to control Phytophthora by many researchers. Previous studies indicated that the effect of bio-products on pathogenic resistance and plant growth stimulation was significant. For example, Aravind et al. successfully isolated Phytophthora antagonism from 71 endophytic strains [8] and Jasim et al. isolated endophytic Klebsiella sp.-a member of the Enterobacteriaceae-from black pepper that could promote black pepper growth and inhibit Phytophthora [34]. It was found that Bacillus megaterium could produce several strong inhibitory antibiotics that can resist Phytophthora capsici, Pythium myriotylum, and Rhizotocnia solani [35]. Moreover, three endophytic bacteria-Enterobacter cancerogenus, Enterobacter cloacae and Enterobacter asburiae - significantly inhibited the growth of Phytoph- 
thora capsici [30]. One of our recent studies found that Bacillus amyloliquefaciens EB.EK2, isolated from 106 endophytic isolates, produced seven potent biochemical compounds to inhibit Phytophthora [30]. In another of our studies [9], we successfully isolated the Bacillus velezensis RB. DS29 strain, which is a promising antifungal rhizobacteria. Interestingly, this strain could inhibit up to $98.8 \%$ of Phytophthora growth by producing various enzymes and biochemical compounds; this was confirmed by in vivo assays on the black pepper seedlings in the green house. We also carried out a phylogenetic analysis of 352 endophytic bacteria isolated from 90 root samples in the farms in the Central Highlands of Vietnam for Phytophthora antagonism under in vitro assay conditions [36]. The results showed that Bacillus velezensis and Bacillus amyloliquefaciens exhibit pathogenic fungal antagonism and plant growth promotion activities. Most studies have reported the results of rhizosphere bacteria and endophytic bacteria on the plant growth promotion and antifungal activity using in vitro or greenhouse-based experiments $[8,9,27,28,30,34,36]$. To date, few works have researched the impact of rhizosphere bacteria and endophytic bacteria on the growth and disease resistance of black pepper in the field. Based on the promising results of our previous studies, this project was carried out to evaluate the anti-pathogenic fungal activity and growth stimulation of both rhizosphere bacteria and endophytic bacteria in the black pepper farms in the Central Highlands of Vietnam.

\section{Materials and Methods}

\subsection{Materials}

Black pepper plants (Piper nigrum L.) (Vinh Linh local cultivar) at the productive stage (6 years old) and grown at farms with red-basalt soil in the Central Highlands of Vietnam were selected for the investigation (Figure 1). The experimental field of black pepper locate at $12^{\circ} 30^{\prime} 47.6^{\prime \prime} \mathrm{N}, 107^{\circ} 42^{\prime} 09.2^{\prime \prime}$ E which belongs to Dakmil district, Daknong province) where has an average altitude of $500 \mathrm{~m}$ and subtropical climate with an average temperature of $22.3{ }^{\circ} \mathrm{C}$, annual average humidity of $85 \%$, and annual average rainfall of $1700-1800 \mathrm{~mm}$.

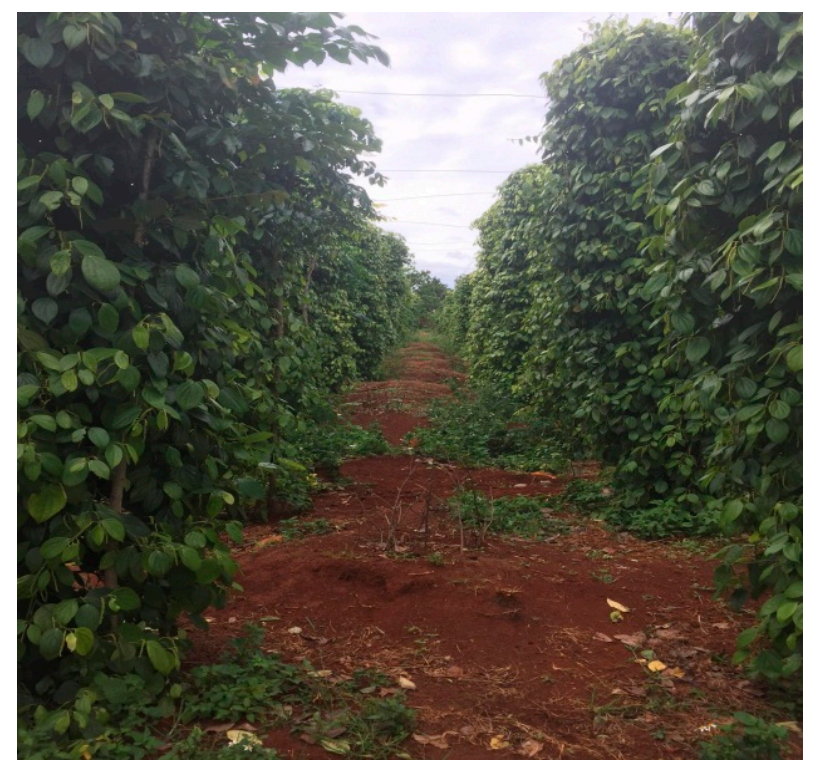

Figure 1. Black pepper farm (plants six-years old) at Dak Mil district, Dak Nong province, located in the Central Highlands of Vietnam.

The bacterial strains with anti-Phytophthora and plant growth stimulation activity that were used in the bio-products which were produced are shown in Table 1. 
Table 1. The bacterial strains used for application in the black pepper farm.

\begin{tabular}{|c|c|c|c|}
\hline No. & Selected Bacterial Strains & Characteristics and Bioactivities of the Strains & References \\
\hline 1 & Bacillus velezensis KN12 & \multirow{2}{*}{ Endophytic bacteria, Phytopthora antagonist } & \multirow{2}{*}{ [36] } \\
\hline 2 & B. amyloliquefaciens DL1 & & \\
\hline 3 & B. velezensis ĐS 29 & \multirow{2}{*}{ Rhizosphere bacteria, Phytopthora antagonist } & \multirow{2}{*}{ [9] } \\
\hline 4 & B. subtilis $\mathrm{BH} 15$ & & \\
\hline 5 & B. subtilis V1.21 & \multirow{2}{*}{ Plant growth promoting activity } & \multirow{2}{*}{ [28] } \\
\hline 6 & B. cereus CS30 & & \\
\hline
\end{tabular}

Bio-products containing the bacteria were produced according to the following steps:

- Biomass production in a bioreactor (liquid product): The growth optimal conditions included a TSB media for 12-24 h for microbial breeding cultivation, and $8 \mathrm{~h}$ fermentation at a temperature of $35^{\circ} \mathrm{C}, 150 \mathrm{rpm} / \mathrm{m}$.

- $\quad$ Producing bacteria powder products: Liquid biomass products were mixed with a carrier material, such as talc, lactose, or corn starch, at a particular ratio, and then were dried on a tray for 5 days. Consequently, the mixed powder product was crushed, homogenized and stored in a sterilized vacuum bag.

The powder bio-product had a bacterial density of $10^{9} \mathrm{CFU} \cdot \mathrm{g}^{-1}$.

\subsection{Experimental Methods}

The treatments with bio-products were made by spreading the powder around the stump of black pepper plants in the farms. The composition of the bio-products under different treatments are described in Table 2.

Table 2. Composition of the bio-products used in in the experiments.

\begin{tabular}{ccc}
\hline Treatment & Bio-Product-I (g/stump) & Bio-Product-II (g/stump) \\
\hline Control & 0 & 0 \\
\hline Formula 1 & 10 & 15 \\
\hline Formula 2 & 10 & 30 \\
\hline Formula 3 & 20 & 15 \\
\hline Formula 4 & 20 & 30 \\
\hline Formula 5 & 30 & 15 \\
\hline Formula 6 & 30 & 30 \\
\hline
\end{tabular}

Bio-Product-I contained Phytophthora antagonistic endophytic bacteria and plant growth-promoting activity microorganisms. Bio-Product-II contained Phytophthora antagonistic rhizosphere bacteria and plant growth-promoting activity microorganisms.

The formulas were contained the following quantities of different bacteria:

Formula 1: $2.5 \mathrm{~g}$ B. velezensis KN12 $+2.5 \mathrm{~g}$ B. amyloliquefaciens DL1 $+3.75 \mathrm{~g}$ B. velezensis DS29 + $3.75 \mathrm{~g}$ B. subtilis BH15 + 6.25 g B. subtilis V1.21 + 6.25 g B. cereus CS30.

Formula 2: $2.5 \mathrm{~g}$ B. velezensis KN12 $+2.5 \mathrm{~g}$ B. amyloliquefaciens DL1 $+7.5 \mathrm{~g}$ B. velezensis $\mathrm{DS} 29+7.5 \mathrm{~g}$ B. subtilis BH15 + $10 \mathrm{~g}$ B. subtilis V1.21 + $10 \mathrm{~g}$ B. cereus CS30.

Formula 3: $5 \mathrm{~g}$ B. velezensis KN12 $+5 \mathrm{~g}$ B. amyloliquefaciens DL1 $+3.75 \mathrm{~g}$ B. velezensis DS29 + $3.75 \mathrm{~g}$ B. subtilis BH15 + 8.75 g B. subtilis V1.21 + 8.75 g B. cereus CS30.

Formula 4: $5 \mathrm{~g}$ B. velezensis KN12 $+5 \mathrm{~g}$ B. amyloliquefaciens DL1 $+7.5 \mathrm{~g}$ B. velezensis DS29 + 7.5 g B. subtilis BH15 + $12.5 \mathrm{~g}$ B. subtilis V1.21 + $12.5 \mathrm{~g}$ B. cereus CS30.

Formula 5: $7.5 \mathrm{~g}$ B. velezensis KN12 + 7.5 g B. amyloliquefaciens DL1 $+3.75 \mathrm{~g}$ B. velezensis DS29 + 3.75 g B. subtilis BH15 + 11.25 g B. subtilis V1.21; $+11.25 \mathrm{~g}$ B. cereus CS30. 
Formula 6: $7.5 \mathrm{~g}$ B. velezensis KN12 + 7.5 g B. amyloliquefaciens DL1 + 7.5 g B. velezensis DS29 + 7.5 g B. subtilis BH15 + $15 \mathrm{~g}$ B. subtilis V1.21 + $15 \mathrm{~g}$ B. cereus CS30.

The experiments were designed by using a Randomized Complete Block Design (RCBD) method with 7 treatments and 30 stumps per treatment. All experiments were repeated in triplicate.

\subsection{Sampling Method}

Fresh soil and black pepper root samples of approximately $40-50 \mathrm{~g}$ and 5-10 g, respectively, were collected simultaneously from bio-product treated and control formulas before treatment and after 1 and 6 months of the treatment. The samples of each treatment were collected at five cross-angle positions at $0-30 \mathrm{~cm}$ depths at a distance of about $20-40 \mathrm{~cm}$ from the cylinder; they were then well mixed to obtain homogenized samples. The samples were transported in sterilized polyethylene bags in an ice pack to the laboratory. When samples could not be processed immediately, they were stored at $4{ }^{\circ} \mathrm{C}$ for no longer than $24 \mathrm{~h}$.

The following criteria were evaluated to compare the efficiency of the treatments: Total microbial density; Phytophthora spp. density; Fusarium spp. density $\left(\mathrm{CFU} \cdot \mathrm{g}^{-1}\right)$; chlorophyll $\mathrm{a}$, chlorophyll b $\left(\mathrm{mg} \cdot \mathrm{g}^{-1} \mathrm{FW}\right)$; photosynthesis intensity $\left(\mu \mathrm{mol} \cdot \mathrm{m}^{-2} \cdot \mathrm{s}^{-1}\right)$; increase in branch length $(\mathrm{cm})$; increase in branch number, leaf area $\left(\mathrm{cm}^{2}\right)$; weight of 10 spikes $(\mathrm{g})$; number of fruit/spike; the ratio of the pepper kernel; dry yield (Ton $\left.\cdot \mathrm{ha}^{-1}\right)$; weight $\left(\mathrm{g} \cdot \mathrm{L}^{-1}\right)$; and percentage of black pepper yellowing symptom (\%).

\subsection{Analytical Methods}

\subsubsection{Determination of Microbiological Density}

Total cultivable microbiological density was determined by a culture-dependent method consisting of counting the number of colonies growing on Plate Count Agar (PCA) medium [37] containing casein peptone $5.0 \mathrm{~g} \cdot \mathrm{L}^{-1}$; yeast extract $2.5 \mathrm{~g} \cdot \mathrm{L}^{-1}$; dextrose $1.0 \mathrm{~g} \cdot \mathrm{L}^{-1}$; agar $15.0 \mathrm{~g} \cdot \mathrm{L}^{-1}$. The fresh soil samples were mixed, finely ground in a sterile porcelain mortar, and $1 \mathrm{~g}$ of the sample was added to $9 \mathrm{~mL}$ of sterile physiological saline, homogenized and diluted. Using a sterile pipette, $0.1 \mathrm{~mL}$ of the sample solution at different dilution rates was pipetted into a petri dish containing PCA medium and spread evenly with a glass rod replicated three times per selective medium. Petri plates were incubated at room temperature for 2-3 days and colonies were counted. Selected dishes with colonies numbering from 30-300 to calculate the results. The density of cultivable microorganisms in $1 \mathrm{~g}$ of sample was calculated as follows:

$$
\mathrm{A}\left(\mathrm{CFU} \cdot \mathrm{g}^{-1}\right)=\mathrm{N} /\left(\mathrm{n}_{1} \cdot \mathrm{V} \cdot \mathrm{f}_{1}+\ldots+\mathrm{n}_{\mathrm{i}} \cdot \mathrm{V} \cdot \mathrm{f}_{\mathrm{i}}\right)
$$

where $\mathrm{A}$ is the colony forming unit; $\mathrm{N}$ is the total count of colonies on the selected plates; $n_{i}$ is the number of colonies at dilution level $i ; V$ is the volume of sample solution $(m L)$ implanted in each plate; and $f_{i}$ is the equivalent dilution.

\subsubsection{Determination of the Density of Fungal Pathogens in the Soil}

The soil samples were diluted with saline solution, inoculated into PDA medium amended with $0.001 \%$ chloramphenicol and incubated at room temperature for 3-5 days. The density of Phytophthora sp., Fusarium sp. was determined based on a morphological identification for fungi [38].

\subsubsection{Measurement of Antagonistic Effect}

We used the Henderson-Tilton formula [39] to calculate the antagonistic effect:

$$
\text { Corrected } \%=\left(1-\frac{\mathrm{n} \text { in Co before treatment } * \mathrm{n} \text { in T after treatment }}{\mathrm{n} \text { in Co after treatment } * \mathrm{n} \text { in T before treatment }}\right) * 100
$$

where $\mathrm{n}$ is the microbe's population, $\mathrm{T}$ is the treated sample, and Co is the control sample. 


\subsubsection{Measurements of Chlorophyll Content and Photosynthesis Activity}

Chlorophyll content was determined according to the method described in [40]. Briefly, $1 \mathrm{~g}$ of finely cut fresh leaves was taken and ground with $20-40 \mathrm{~mL}$ of $80 \%$ acetone. It was then entrifuged at 5000-10,000 rpm for $5 \mathrm{~min}$. The supernatant was transferred and the procedure was repeated until the residue became colorless. The absorbance was measured using a spectrophotometer (Jasco V-630 UV-Vis/NIR Photometers) at 646 and $664 \mathrm{~nm}$, and chlorophyll content was calculated according to the following equations:

$$
\begin{aligned}
& {[\text { Chl-a }]=0.0127 \times \mathrm{A}_{664}-0.00269 \times \mathrm{A}_{646}} \\
& {[\text { Chl-b }]=0.0229 \times \mathrm{A}_{646}-0.00468 \times \mathrm{A}_{664}}
\end{aligned}
$$

The intensity of photosynthesis $\left(\mu \mathrm{mol} \cdot \mathrm{m}^{-2} \cdot \mathrm{s}^{-1}\right)$ was calculated using the US PP System TPS-2 photosynthetic intensity meter (PP Systems, Amesbury, MA, USA).

\subsubsection{Measurement of Growth Criteria}

The increase in branch length was measured by the length of secondary branches. The increase in branch number was calculated as the number of new branches numbers created on the secondary branches. The percentage of black pepper yellowing symptom (\%) was calculated as the proportion of black pepper stumps with over $70 \%$ yellowing leaves of the total number of surveyed plant stumps. The leaf area was measured using LeafByte software [41].

\subsection{Data Analysis}

All experiments were repeated in triplicate and the data were analyzed using onefactor analysis of variance (ANOVA) with a confidence interval of $95 \%$. The results were presented as mean values \pm standard deviation. The significance of differences among the mean values was compared using Duncan's multiple-range test $(p \leq 0.05)$ using Statistical Analysis Software (SAS 9.4) purchased from SAS Institute Taiwan Ltd. (Taipei, Taiwan).

\section{Results and Discussion}

\subsection{Effect of Bio-Products Containing Rhizosphere Bacteria and Endophytic Bacteria on Total} Microorganism Density in the Soil

The biological control of plant disease is the suppression of populations of plant pathogens by beneficial organisms [40]. Here, we studied the effects of bio-products containing rhizosphere and endophytic bacteria on pathogenic fungus and the growth stimulation of black pepper using seven formulas containing different compositions of bio-products (Table 2). There were no significant differences in the total microorganism density among samples before the treatments (Table 3) (around $2 \times 10^{7} \mathrm{CFU} \cdot \mathrm{g}^{-1}$ ). This means that the platform of the experimental farm was uniform. After one month, the total microorganism density in the control formula increase slightly from $2.3 \times 10^{7} \mathrm{CFU} \cdot \mathrm{g}^{-1}$ to $3.9 \times 10^{7} \mathrm{CFU} \cdot \mathrm{g}^{-1}$, but the increase in all treated formulas was significantly greater than the control. Formula 6 showed the strongest effect after one month, with a 7.8-fold increase in the total microorganism density in the treated samples compared to before being treated by bio-products (from $2.15 \times 10^{7} \mathrm{CFU} \cdot \mathrm{g}^{-1}$ to $16.9 \times 10^{7} \mathrm{CFU} \cdot \mathrm{g}^{-1}$ ); and it was 4.3-times higher than the control $\left(3.9 \times 10^{7} \mathrm{CFU} \cdot \mathrm{g}^{-1}\right)$. However, the total microbial density in the soil tended to decrease after 6 months of treatment because it occurs normally during the dry season. The results indicate that the treatment with formula 6 had a microorganism density that was 3.6-times higher than the control after six months $\left(6.8 \times 10^{7} \mathrm{CFU} \cdot \mathrm{g}^{-1}\right.$ compared to $1.9 \times 10^{7} \mathrm{CFU} \cdot \mathrm{g}^{-1}$ ) (Table 3).

The microorganism system in the soil plays an important role that directly and indirectly affects plant growth, development and pathogenic resistance. Their activities include biosynthesis; mineralization; metabolism of nutrients including nitrogen fixation and decomposition, as well as phosphorus fixation; and biosynthesis of plant hormones including auxin, cytokinin, giberellin [42]. These activities can stimulate plants to increase 
their mobilization and increase their ability to absorb nutrients from the environment [43]. On the other hand, microorganisms can compete for nutrition or synthesize harmful substances to inhibit or destroy unfavorable microorganisms. Therefore, using bio-products to increase density of microorganisms in soil is very important to encourage sustainable plant growth and development.

Table 3. Effects of microbiological bio-products on total microorganism density in the soil of a black pepper farm.

\begin{tabular}{cccc}
\hline \multirow{2}{*}{ Treatment } & \multicolumn{3}{c}{ Total Microorganisms $\left(\times \mathbf{1 0}^{\mathbf{7}} \mathbf{C F U} \cdot \mathbf{g}^{\mathbf{1}}\right)$} \\
\cline { 2 - 4 } & Before Treatment & 1-Month Treatment & 6-Month Treatment \\
\hline Control & $2.30 \pm 0.08$ & $3.90 \pm 0.06^{\mathrm{f}}$ & $1.91 \pm 0.04^{\mathrm{d}}$ \\
\hline Formula 1 & $2.26 \pm 0.09$ & $4.13 \pm 0.04^{\mathrm{f}}$ & $2.57 \pm 0.07^{\mathrm{b}}$ \\
\hline Formula 2 & $2.22 \pm 0.16$ & $7.75 \pm 0.09^{\mathrm{e}}$ & $2.36 \pm 0.13^{\mathrm{bc}}$ \\
\hline Formula 3 & $1.84 \pm 0.15$ & $10.1 \pm 0.14^{\mathrm{d}}$ & $2.14 \pm 0.04^{\mathrm{cd}}$ \\
\hline Formula 4 & $1.97 \pm 0.04$ & $11.5 \pm 0.08^{\mathrm{b}}$ & $2.5 \pm 0.05^{\mathrm{b}}$ \\
\hline Formula 5 & $1.92 \pm 0.10$ & $11.0 \pm 0.09^{\mathrm{c}}$ & $2.11 \pm 0.05^{\mathrm{cd}}$ \\
\hline Formula 6 & $2.15 \pm 0.06$ & $16.9 \pm 0.17^{\mathrm{a}}$ & $6.8 \pm 0.20^{\mathrm{a}}$ \\
\hline ANOVA & $\mathrm{NS}$ & $* *$ & $* *$ \\
\hline
\end{tabular}

$\overline{\text { Means } \pm \text { standard errors within a column followed by the same superscript letter(s) are not significantly different }}$ according to the Duncan's multiple range test. NS: non-significant differences, ${ }^{* *} p<0.01$.

\subsection{Effect of Bio-Products Containing Rhizosphere Bacteria and Endophytic Bacteria on Root Pathogens of Black Pepper}

The antagonistic effect of bio-products on Phytophthora spp.

The data show that Phytophthora density in the soil and roots was significantly reduced in all bio-product-treated formulas after one month, and continued to decrease after six months (Table 4). This suggests that the beneficial bacteria in the bio-products inhibited Phytophthora spp. Formula 6 had the greatest inhibitory effect on Phytophthora density, decreasing from $4.54 \times 10^{2} \mathrm{CFU} \cdot \mathrm{g}^{-1}$ in the soil and $1.04 \times 10^{1} \mathrm{CFU} \cdot \mathrm{g}^{-1}$ in the roots after one month, to $2.69 \times 10^{2} \mathrm{CFU} \cdot \mathrm{g}^{-1}$ in the soil and $0.39 \times 10^{1} \mathrm{CFU} \cdot \mathrm{g}^{-1}$ in the roots after six months.

The Phytophthora inhibitory effect of endophytic bacteria B. velezensis KN12 and B. amyloliquefaciens DL1 bio-products has been reported by Ngo et al. [36]. They found that the bio-product has a very strong inhibitory effect in vitro by chitinase, and proteases. Moreover, Trinh et al. [9] selected rhizobacteria B. velezensis DS29, from 8 potent Phytopthora antagonistic rhizosphere strains. B. velezensis DS29 strain showed an extremerly high inhibition against the growth of Phytophthora (98.75\%) in vitro assay. This inhibitory effect of B. velezensis DS29 on Phytophthora growth was attributed to chitinase, protease, glucanase and other biochemical compounds produced by this strain such as pregn-4-ene-3, 20-dione, 17-hydroxy-6-methyl-, bis (O-methyloxime)]; disulfide, methyl 1-(methylthio) propyl; propanoic acid, 2-methyl-, decyl ester; benzofuranyl derivatives; and propanethioic acid, S-pentyl ester, metronidazole-oh and sulfadiazine. Because of their antifungal activity, Bacillus velezensis strains have also been considered as a potent biocontrol agents for plant protection [44-46].

In addition, Trinh et al., and Ngo et al. [9,36] showed the role of these bacteria in controlling potency of Phytophthora in soil and roots on black pepper seedlings in the greenhouse. In our experiment, the data indicated that higher doses of the bio-products resulted in lower density of Phytophthora both in the soil and in the roots, which might be due to the increase in microorganisms total in the soil (Tables 3 and 4). 
Table 4. Phytophthora spp. density in the soil and in the roots of black pepper before and after of bio-product treatment.

\begin{tabular}{|c|c|c|c|c|c|c|}
\hline \multirow[t]{2}{*}{ Treatment } & \multicolumn{3}{|c|}{$\begin{array}{l}\text { Phytophthora Density in the Soil } \\
\qquad\left(\times 10^{2} \text { CFU.g }{ }^{-1}\right)\end{array}$} & \multicolumn{3}{|c|}{$\begin{array}{l}\text { Phytophthora Density in the Root } \\
\qquad\left(\times 10^{1} \text { CFU } \cdot g^{-1}\right)\end{array}$} \\
\hline & $\begin{array}{l}\text { Before } \\
\text { Treatment }\end{array}$ & $\begin{array}{l}\text { 1-Month } \\
\text { Treatment }\end{array}$ & $\begin{array}{l}\text { 6-Month } \\
\text { Treatment }\end{array}$ & $\begin{array}{c}\text { Before } \\
\text { Treatment }\end{array}$ & $\begin{array}{l}\text { 1-Month } \\
\text { Treatment }\end{array}$ & $\begin{array}{l}\text { 6-Month } \\
\text { Treatment }\end{array}$ \\
\hline Control & $9.82 \pm 0.06^{b}$ & $9.2 \pm 0.12^{c}$ & $8.68 \pm 0.1^{f}$ & $2.23 \pm 0.06$ & $2.8 \pm 0.34^{c}$ & $1.94 \pm 0.03^{f}$ \\
\hline Formula 1 & $9.55 \pm 0.07^{a b}$ & $7.05 \pm 0.09^{b}$ & $8.05 \pm 0.08^{\mathrm{e}}$ & $2.25 \pm 0.04$ & $2.39 \pm 0.11^{b c}$ & $1.23 \pm 0.08^{\mathrm{e}}$ \\
\hline Formula 2 & $10.83 \pm 0.41^{\mathrm{c}}$ & $9.08 \pm 0.12^{c}$ & $7.11 \pm 0.1^{\mathrm{d}}$ & $2.16 \pm 0.05$ & $2.19 \pm 0.1^{b}$ & $1.06 \pm 0.07^{\mathrm{cd}}$ \\
\hline Formula 3 & $10.81 \pm 0.45^{c}$ & $9.17 \pm 0.04^{c}$ & $6.33 \pm 0.09^{c}$ & $2.13 \pm 0.06$ & $2.17 \pm 0.15^{b}$ & $1.17 \pm 0.05^{\mathrm{de}}$ \\
\hline Formula 4 & $9.65 \pm 0.11^{a b}$ & $7.17 \pm 0.06^{b}$ & $7.22 \pm 0.06^{\mathrm{d}}$ & $2.2 \pm 0.08$ & $1.53 \pm 0.06^{\mathrm{a}}$ & $0.92 \pm 0.04^{c}$ \\
\hline Formula 5 & $8.98 \pm 0.06^{a}$ & $4.59 \pm 0.08^{a}$ & $5.27 \pm 0.08^{b}$ & $2.32 \pm 0.03$ & $1.16 \pm 0.07^{\mathrm{a}}$ & $0.75 \pm 0.03^{b}$ \\
\hline Formula 6 & $9.5 \pm 0.14^{\mathrm{ab}}$ & $4.54 \pm 0.18^{a}$ & $2.69 \pm 0.08^{a}$ & $2.36 \pm 0.14$ & $1.04 \pm 0.04^{\mathrm{a}}$ & $0.39 \pm 0.04^{a}$ \\
\hline ANOVA & * & $* *$ & $* *$ & NS & $* *$ & $* *$ \\
\hline
\end{tabular}

Means \pm standard errors within a column followed by the same superscript letter(s) are not significantly different according to the Duncan's multiple range test. NS: non-significant differences, ${ }^{*} p<0.05,{ }^{* *} p<0.01$.

Based on Phytophthora density, the antagonistic effect was calculated using HendersonTrilton formula, and result showed that Phytophthora antagonistic effect of formula 6 reached $49 \%$ and $68 \%$ after 1 month and 6 months in the soil, and reach $64 \%$ and $81 \%$ after 1 month and 6 months in the roots compared to control at the same time (Figure 2).

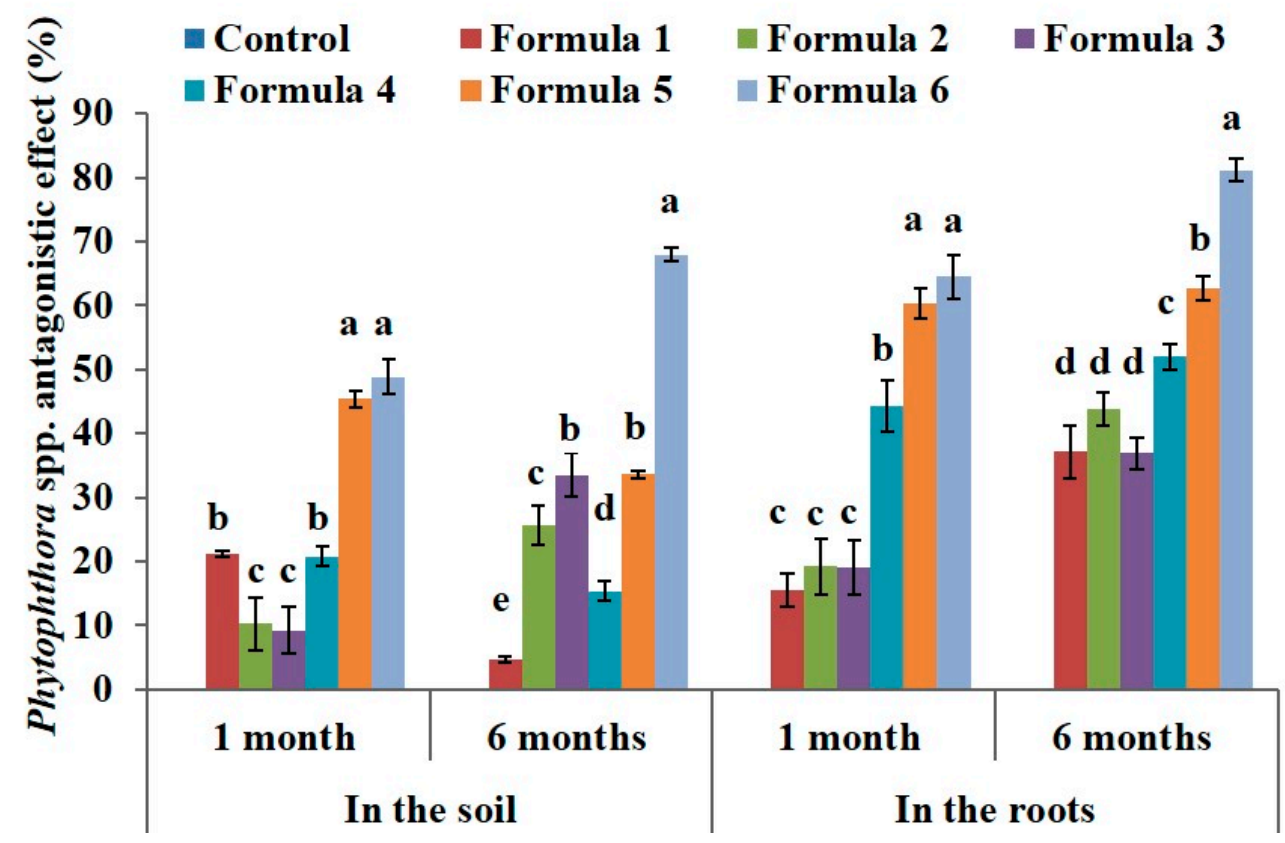

Figure 2. The effect of bio-products on Phytophthora spp. in the soil and in the roots at the black pepper farm after 1 month and 6 months of treatment. The experiment was designed 7 formulas involve control formula and six treated formulas as mentioned in Table 2. Data represent mean and error bars from three different replicates; each replicate contained at least 30 individual black pepper stumps per treatment. All statistical analyses including one-way variance analysis (ANOVA) and Duncan's multi range test were carried out using Statistical Analysis Software (SAS 9.4). Different letters indicate statistically significant differences among the values of formulas analyzed after 1 month or 6 months $(p<0.05)$. By using the Henderson-Tilton formula to calculate the antagonistic effect, mean of control formula is always zero value.

Using bio-products in the treated plots enhanced total cultivable microorganism and the beneficial microorganisms in the soil contributes to increase in the antagonism among microorganism system and nutrition and living space competitive to the pathogenic 
fungi, especially, application of bio-products including effective microorganism in this experiment showed a higher effectiveness. These effects are similar to some researches before [9,36,47]. Nguyen et al. [47] found that the effective microorganisms released enzymes such as chitinases, proteases, glucanases, and antibiotics into the soil which can suppress pathogenic fungus which was determined $\mathrm{r}$ correlation between soil effective microorganisms and density of pathogen fungi was $-0.84(n=27)$ [47].

There are many different activity modes of Bio-product agents protect crops such as induce resistance against infections by a pathogen in plant tissues without direct antagonistic interaction with the pathogen $[48,49]$ or indirect interaction with pathogens is competition for nutrients and space [50], or interact directly with the pathogen by hyperparasitism or antibiosis [51].

Many studies have reported the relationship between plant growth-promoting bacteria and soil pathogens. The diversity of bacteria in the tomato root-zone was inversely correlated with the severity of disease caused by P. lycopersici [8]. In another study, fungal diversity was also inversely correlated with the development of adzuki stem rot caused by A. gregatum [9].

The antagonistic effects of bio-products on Fusarium spp.

The results in Table 5 show that bio-product treatments were able to suppress Fusarium spp. development. Fusarium density in the soil and in the roots tended to decrease after 1 month and 6 months of treatment. The density of Fusarium spp. was lowest using formula 5 and formula 6 compared with the control and other formulas. Specifically, the Fusarium density using formula 6 decreased from $8 \times 10^{2} \mathrm{CFU} \cdot \mathrm{g}^{-1}$ to $3 \times 10^{2} \mathrm{CFU} \cdot \mathrm{g}^{-1}$ after $1 \mathrm{month}$, and dropped to $1.5 \times 10^{2} \mathrm{CFU} \cdot \mathrm{g}^{-1}$ after 6 months in the rhizosphere; Fusarium spp. was not detected in the root after 6 months of treatment (Table 5). This suggests that bio-products containing rhizosphere and endophytic bacteria have potential as biocontrol agents for the control of pathogenic fungi.

Table 5. Fusarium spp. density in the soil and in the roots of black pepper before and after treatment with bio-products.

\begin{tabular}{|c|c|c|c|c|c|c|}
\hline \multirow[t]{2}{*}{ Treatment } & \multicolumn{3}{|c|}{$\begin{array}{l}\text { Fusarium Density in the Soil } \\
\qquad\left(\times 10^{2} \mathrm{CFU} \cdot \mathrm{g}^{-1}\right)\end{array}$} & \multicolumn{3}{|c|}{$\begin{array}{l}\text { Fusarium Density in the Roots } \\
\qquad\left(\times 10^{1} \text { CFU. } \mathrm{g}^{-1}\right)\end{array}$} \\
\hline & $\begin{array}{c}\text { Before } \\
\text { Treatment }\end{array}$ & $\begin{array}{l}\text { 1-Month } \\
\text { Treatment }\end{array}$ & $\begin{array}{l}\text { 6-Month } \\
\text { Treatment }\end{array}$ & $\begin{array}{c}\text { Before } \\
\text { Treatment }\end{array}$ & $\begin{array}{l}\text { 1-Month } \\
\text { Treatment }\end{array}$ & $\begin{array}{l}\text { 6-Month } \\
\text { Treatment }\end{array}$ \\
\hline Control & $8.21 \pm 0.05^{a}$ & $7.23 \pm 0.05^{g}$ & $5.98 \pm 0.09 \mathrm{~g}$ & $3.48 \pm 0.07$ & $3.44 \pm 0.11^{\mathrm{e}}$ & $3.98 \pm 0.03^{f}$ \\
\hline Formula 1 & $8.46 \pm 0.2^{a}$ & $6.17 \pm 0.09^{f}$ & $5.44 \pm 0.05^{\mathrm{f}}$ & $3.28 \pm 0.09$ & $3.1 \pm 0.08^{\mathrm{d}}$ & $3.01 \pm 0.06^{d}$ \\
\hline Formula 2 & $9.46 \pm 0.12^{b}$ & $4.11 \pm 0.08^{c}$ & $4.29 \pm 0.1^{c}$ & $3.54 \pm 0.06$ & $2.77 \pm 0.09^{c}$ & $3.15 \pm 0.07 \mathrm{de}$ \\
\hline Formula 3 & $8.33 \pm 0.22^{a}$ & $5.24 \pm 0.07^{\mathrm{d}}$ & $4.82 \pm 0.05^{\mathrm{e}}$ & $3.69 \pm 0.11$ & $2.19 \pm 0.12^{b}$ & $3.22 \pm 0.08^{\mathrm{e}}$ \\
\hline Formula 4 & $9.19 \pm 0.18^{b}$ & $5.66 \pm 0.08^{e}$ & $4.55 \pm 0.08^{\mathrm{d}}$ & $3.55 \pm 0.14$ & $1.96 \pm 0.04^{b}$ & $2.01 \pm 0.06^{c}$ \\
\hline Formula 5 & $8.28 \pm 0.1^{a}$ & $3.54 \pm 0.06^{b}$ & $3.17 \pm 0.06^{b}$ & $3.67 \pm 0.09$ & $1.53 \pm 0.16^{\mathrm{a}}$ & $0.68 \pm 0.02^{b}$ \\
\hline Formula 6 & $8.47 \pm 0.19^{a}$ & $3.00 \pm 0.07^{a}$ & $1.48 \pm 0.08^{a}$ & $3.48 \pm 0.11$ & $1.33 \pm 0.07^{\mathrm{a}}$ & $0.0 \pm 0.0^{a}$ \\
\hline ANOVA & ** & ** & ** & NS & ** & $* *$ \\
\hline
\end{tabular}

Means \pm standard errors within a column followed by the same superscript letter(s) are not significantly different according to the Duncan's multiple range test. NS: non-significant differences, ${ }^{* *} p<0.01$.

The results for formula 6 showed that the antagonistic effect was $59.85 \%$ $\left(3.00 \times 10^{2} \mathrm{CFU} \cdot \mathrm{g}^{-1}\right)$, which represents a 2.8 -fold decrease compared to that of the sample before treatment and 2.4-fold decrease compared to the control $\left(7.23 \times 10^{2} \mathrm{CFU} \cdot \mathrm{g}^{-1}\right)$ (Table 5). Similarly, the Fusarium density after 6 months of treatment tended to decrease; the lowest density was attributed to the treatment with formula $6\left(1.48 \times 10^{2} \mathrm{CFU} \cdot \mathrm{g}^{-1}\right)$ and the efficiency was $80.23 \%$ (Figure 3). These results indicate that the Fusarium antagonistic effect is similar to that shown by Nguyen [45]. 


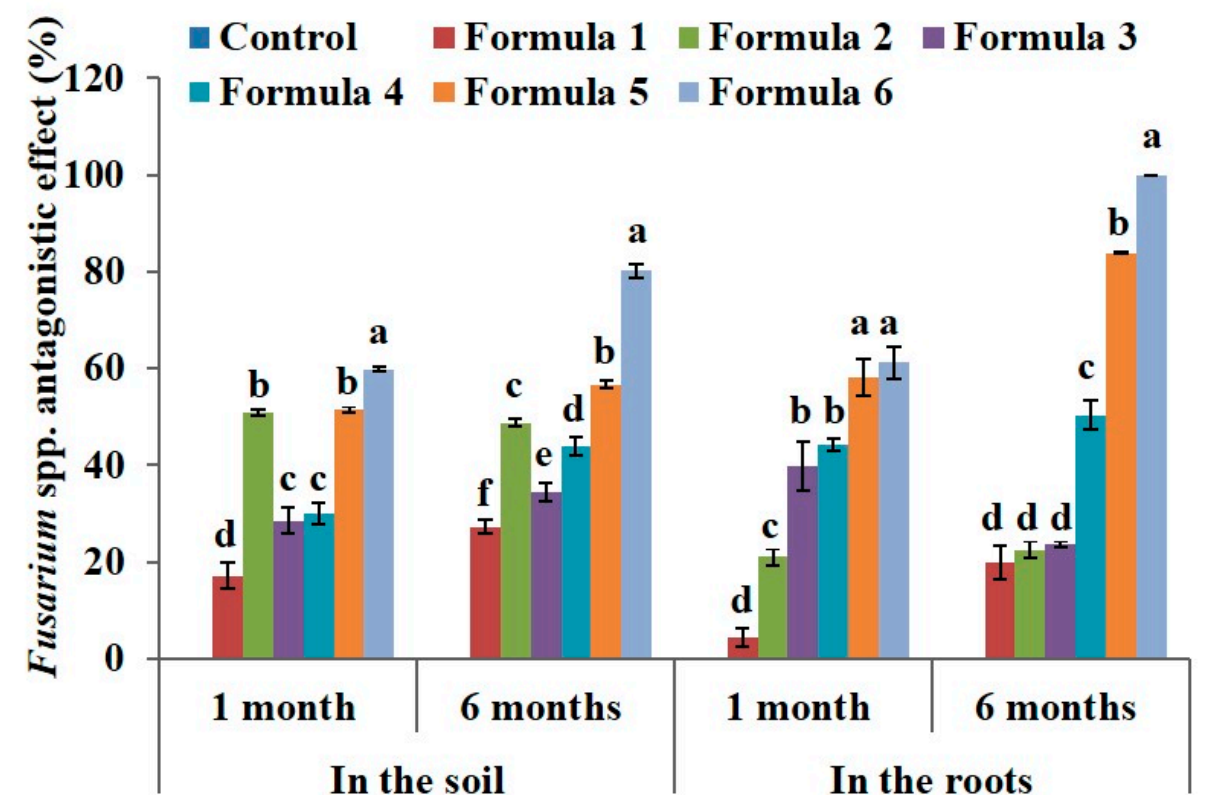

Figure 3. The effect of bio-products on Fusarium spp. in the soil and in the roots at the black pepper farm after 1 month and 6 months of treatment. The experiment was designed 7 formulas involve control formula and six treated formulas as mentioned in Table 2. Data represent mean and error bars from three different replicates; each replicate contained at least 30 individual black pepper stumps per treatment. All statistical analyses including one-way variance analysis (ANOVA) and Duncan's multi range test were carried out using Statistical Analysis Software (SAS 9.4). Different letters indicate statistically significant differences among the values of formulas analyzed after 1 month or 6 months $(p<0.05)$. By using the Henderson-Tilton formula to calculate the antagonistic effect, mean of control formula is always zero value.

After one month of treatment, the Fusarium density in the roots significantly decreased in the treatment with formula $5\left(1.53 \times 10^{1}\right)$ and formula $6\left(1.33 \times 10^{1} \mathrm{CFU} \cdot \mathrm{g}^{-1}\right)$ with antagonistic effects of $58.15 \%$ and $61.15 \%$, respectively (Figure 3 ). After six months of treatment, the Fusarium density slightly increased in treatments with formula 1-4, but was dramatically decreased to $0.68 \times 10^{1} \mathrm{CFU} \cdot \mathrm{g}^{-1} \mathrm{CFU} \cdot \mathrm{g}^{-1}$ in the treatment with formula 5. The treatment with formula 6 was free of disease with an antagonistic effect of $100 \%$ after six months (Figure 3). This suggests that the strains we used had a strong antifungal activity when applied at the farm.

The soil microbial community is known to affect plant health and soil quality. Beneficial microorganisms in the soil play an important role in the metabolism and decomposition of complex organic compounds in the soil, so the growth of beneficial soil microorganisms contributes to the increase in soil fertility.

Bacillus strains applied in this experiment have been reported to be potent agents for the control of pathogenic fungi including Fusarium spp. Bacillus amyloliquefaciens, Bacillus atrophaeus, and Bacillus subtilis were also applied to control diseases of black pepper in the past [52], and the result was proposed that Bacillus showed antifungal activity due to their protease, cellulase, and volatile compounds.

Nguyen et al. [28] showed that Bacillus amyloliquefaciens processed activities of plant growth promotion and disease resistance. This strain produced seven potent antifungal compounds: 1-cyclohexyl-2-(3-methyl-2-propan-2-ylbutyl) guanidine, dibenzoylacetylene; 6-N,7-dimethylquinoline-5, 6-diamine, 2-(1,3-dihydroisoindol-2-yl)- $N$, $N$-diethylethanamine; piperazine 1-butyl-4-(1-phenylpropan-2-yl), 10-(2,6-diphenylpyran-4-ylidene) anthracen9-one, and 3-methyl-2-naphtha- len-1-yl-2-(2-piperidin-1-ylethyl) pentanenitrile. Bacillus velezensis was recently used in sustainable agriculture as biocontrol agent. Bacillus velezensis FZB42 can also synthesize antifungal compounds such as fengycin, bacillomycin D, difficidin, bacilysin, and amylocyclicin $[8,30,33,44,53-55]$. Bacillus velezensis Rc218 and Bacillus 
velezensis $\mathrm{Cc} 09$ have been used in the biocontrol of wilt disease in strawberries, which is caused by Fusarium oxysporium [45,46].

\subsection{Effect of Bio-Products Containing Rhizosphere Bacteria and Endophytic Bacteria on the} Growth of Black Pepper

As shown in Table 6, the chlorophyll a, chlorophyll $\mathrm{b}$ content of black pepper leaves in the treatment with formula 6 was the highest $\left(0.57 \mathrm{mg} \cdot \mathrm{g}^{-1} \mathrm{FW}\right.$ and $\left.0.43 \mathrm{mg} \cdot \mathrm{g}^{-1} \mathrm{FW}\right)$; this was much higher than the control $\left(0.41 \mathrm{mg} \cdot \mathrm{g}^{-1} \mathrm{FW}\right.$ and $\left.0.37 \mathrm{mg} \cdot \mathrm{g}^{-1} \mathrm{FW}\right)$, which is consistent with the increase in photosynthesis intensity $\left(13.03 \mu \mathrm{mol} \cdot \mathrm{m}^{-2} \cdot \mathrm{s}^{-1}\right)$ (Table 6).

Table 6. Effects of bio-products on chlorophyll content, carotene content and photosynthesis intensity of black pepper leaves.

\begin{tabular}{|c|c|c|c|}
\hline Treatment & Chl.a (mg.g ${ }^{-1}$ FW) & Chl.b (mg.g ${ }^{-1}$ FW) & $\begin{array}{l}\text { Photosynthesis Intensity } \\
\quad\left(\mu \mathrm{mol} \cdot \mathrm{m}^{-2} \cdot \mathrm{s}^{-1}\right)\end{array}$ \\
\hline Control & $0.41 \pm 0.001 \mathrm{~g}$ & $0.37 \pm 0.001^{\mathrm{e}}$ & $8.9 \pm 0.91^{c}$ \\
\hline Formula 1 & $0.52 \pm 0.002^{c}$ & $0.33 \pm 0.003^{f}$ & $10.4 \pm 0.56^{b c}$ \\
\hline Formula 2 & $0.49 \pm 0.002 \mathrm{e}$ & $0.38 \pm 0.002^{d}$ & $10.87 \pm 0.94^{\mathrm{abc}}$ \\
\hline Formula 3 & $0.45 \pm 0.001^{\mathrm{f}}$ & $0.42 \pm 0.003^{b}$ & $10.43 \pm 0.3^{b c}$ \\
\hline Formula 4 & $0.50 \pm 0.00^{\mathrm{d}}$ & $0.40 \pm 0.002^{c}$ & $10.4 \pm 1.26^{b c}$ \\
\hline Formula 5 & $0.56 \pm 0.002^{b}$ & $0.41 \pm 0.001^{b}$ & $11.9 \pm 0.25^{a b}$ \\
\hline Formula 6 & $0.57 \pm 0.001^{\mathrm{a}}$ & $0.43 \pm 0.003^{a}$ & $13.03 \pm 0.43^{a}$ \\
\hline ANOVA & $* *$ & ** & * \\
\hline
\end{tabular}

Means \pm standard errors within a column followed by the same superscript letter(s) are not significantly different according to the Duncan's multiple range test. ${ }^{*} p<0.05,{ }^{* *} p<0.01$.

In the further investigation of the effects of microbial bio-products on the growth of black pepper during the commercial period at Dak Nong area, there were no significant differences in branch length and the number of branches between the control and treated formula, but leaf area showed a significant increase for formulas 4, 5, and 6 compared with the control and other formulas (Table 7).

Table 7. Effects of bio-products on growth and yellowing disease of black pepper plants.

\begin{tabular}{ccccc}
\hline Treatment & $\begin{array}{c}\text { Branch Length } \\
\text { Increased } \mathbf{( c m )}\end{array}$ & $\begin{array}{c}\text { The Number of } \\
\text { Increased Branches }\end{array}$ & Leaf Area (cm ${ }^{\mathbf{2})}$ & $\begin{array}{c}\text { The Percentage of } \\
\text { Yellowing Symptom } \mathbf{( \% )}\end{array}$ \\
\hline Control & $6.56 \pm 0.29$ & $2.44 \pm 0.99$ & $48.13 \pm 0.89^{\mathrm{b}}$ & $14.44 \pm 1.11^{\mathrm{d}}$ \\
\hline Formula 1 & $10.19 \pm 2.08$ & $1.78 \pm 0.44$ & $52.56 \pm 8.48^{\mathrm{ab}}$ & $7.78 \pm 1.11^{\mathrm{bc}}$ \\
\hline Formula 2 & $8.33 \pm 1.61$ & $3.67 \pm 1.02$ & $63.09 \pm 3.78^{\mathrm{ab}}$ & $11.11 \pm 1.11^{\mathrm{cd}}$ \\
\hline Formula 3 & $10.25 \pm 1.5$ & $4.00 \pm 0.38$ & $52.83 \pm 1.36^{\mathrm{ab}}$ & $7.78 \pm 1.11^{\mathrm{bc}}$ \\
\hline Formula 4 & $7.49 \pm 1.09$ & $1.33 \pm 0.33$ & $65.01 \pm 7.70^{\mathrm{a}}$ & $6.67 \pm 1.92^{\mathrm{ab}}$ \\
\hline Formula 5 & $10.00 \pm 0.19$ & $3.56 \pm 0.87$ & $67.25 \pm 2.57^{\mathrm{a}}$ & $5.56 \pm 1.11^{\mathrm{ab}}$ \\
\hline Formula 6 & $10.83 \pm 0.25$ & $4.56 \pm 0.87$ & $64.49 \pm 1.33^{\mathrm{a}}$ & $3.33 \pm 0^{\mathrm{a}}$ \\
\hline ANOVA & $\mathrm{NS}$ & $\mathrm{NS}$ & $*$ & $* *$
\end{tabular}

Means \pm standard errors within a column followed by the same superscript letter(s) are not significantly different according to the Duncan's multiple range test. NS: non-significant differences, ${ }^{*} p<0.05,{ }^{* *} p<0.01$.

Leaf yellowing is a disease symptom caused by Phytophthora and Fusarium infecting the roots of black pepper [8,9]. Our evaluation of the yellowing symptoms at the experimental farm showed that treatment with bio-products reduced the prevalence of leaf yellowing. The percentage of leaf yellowing was highest in the control formula (14.4\%), 
while treatment with formula 6 led to the lowest prevalence of leaf yellowing (3.33\%). The rhizosphere bacteria and endophytic bacteria with plant growth stimulation activities used in this trial were selected from 106 bacterial strains. They had the highest nitrogen fixation, phosphorous solubility and IAA biosynthesis activities in a previous study [28]. They exhibited a nitrogen fixation capacity ranging from 10 to $12 \mu \mathrm{g} \mathrm{NH}{ }_{4}^{+} / \mathrm{mL}$, a phosphorous solubilizing activity of $15-18 \mu \mathrm{g} \mathrm{PO}_{4}{ }^{3-} / \mathrm{mL}$, and an IAA production activity of $30-33.65 \mu \mathrm{g} / \mathrm{mL}$, which led to increased $\mathrm{N}$ and $\mathrm{P}$ content in the black pepper leaves. Nguyen et al. [24] also indicated that these strains stimulated the growth and decreased the fatality rate of black pepper seedlings caused by disease in the greenhouse. Trinh et al. [9] found that these rhizosphere bacteria possessed high chintinase, glucanase and protease activity. In addition, they can produce and release many fungal antagonistic compounds. Therefore, their activities may help stimulate the growth of black pepper and reduce the rate of leaf yellowing symptoms. Our obtained results (Table 7) seemed to be similar to those of other studies on black pepper in the nursery, for example, Dastager et al. [56] and Jasim et al. [34]. Recently, some works have reported that endophytic bacteria from crops such as sugarcane, coffee, and tomatoes can fix nitrogen and IAA, and solubilize insoluble phosphorous, contributing to the reduction in chemical fertilizer usage and drought stress.

\subsection{Effect of Bio-Products Containing Rhizosphere Bacteria and Endophytic Bacteria on Crop Productivity and Quality of Black Pepper}

To evaluate the effect of microbiological bio-products on black pepper yield and quality, several physiological parameters were analyzed including the weight of 10 spikes, the number of spikes, the ratio of the pepper kernel, and the final yield of black pepper. As shown in Table 8, the weight of spikes, the number of fruits and the ratio of the pepper kernel increased after treatment with bio- products. The weight of 10 spikes in formulas 5 and 6 treatments was greatest, at $54.74 \mathrm{~g}$ and $55.9 \mathrm{~g}$, respectively. However, the number of fruits/spikes was not significantly different among formulas, even though slight increases were observed in the treatments with formula 1 , formula 5 , and formula 6 . While the ratio of the pepper kernel was similar among the control and formulas 1 to 5, that of formula 6 (Table 8). These results suggest that bio-products application can promote black pepper yield. However, the difference among these treatments depends on the ingredients used and the amount of bio-products applied. The results on plant growth promotion activity of the rhizosphere bacteria and endophytic bacteria (Tables 6-8) show that treatments can enhance the chlorophyll content, photosynthesis intensity and leaf area, leading to an increase in biomass, productivity and quality of black pepper. The results shown in Table 8 also indicated that the black pepper at Formulas 6 had the highest productivity and significant differences just only to Formulas 1 and Control. Formulas 6 using higher dose, but productivity was similar to Formulas 2, 3, 4 and 5. These results recommended that farmers can applied Formulas 2 to 6 to increase in the productivity. In case, to protect from the yellowing symptom, farmers can apply formulas 5 or 6 . If using higher doses than the Formulas 6, farmers have to spend higher costs.

To the best of our knowledge, this is the first study to evaluate the effect of rhizosphere bacteria and endophytic bacteria application on the yield of black pepper at a farm. Some studies on other crops have reported that Bacillus spp. M9 and Bacillus cereus K46 enhanced photosynthesis, effectiveness of water consumption, and growth of the Habanero pepper [57]. Treatment by Bacillus licheniformis could stimulate plant height, leaf area and yield of tomato and pepper [58]. Bacillus amyloliquefaciens $\mathrm{Y} 1$ also improved soil fertility, the microbial system and the growth of black pepper due to their phosphorous solubility and nitrogen fixation activity [54]. 
Table 8. Effect of bio-products on the yield and quality indices of peppercorn.

\begin{tabular}{|c|c|c|c|c|c|}
\hline Treatment & $\begin{array}{l}\text { Weight of } 10 \\
\text { Spikes (g) }\end{array}$ & $\begin{array}{c}\text { Number of } \\
\text { Fruit/Spike (Fruit) }\end{array}$ & $\begin{array}{l}\text { The Ratio of the } \\
\text { Pepper Kernel }\end{array}$ & $\begin{array}{l}\text { Dry Yield } \\
\text { (Ton/ha) }\end{array}$ & (Weight g/L) \\
\hline Control & $36.52 \pm 1.85^{\mathrm{d}}$ & $29.94 \pm 2.42$ & $0.434 \pm 0.0043$ & $3.30 \pm 0.03^{c}$ & $573.33 \pm 1.33^{c}$ \\
\hline Formula 1 & $45.48 \pm 0.42 \mathrm{bc}$ & $39.42 \pm 0.88$ & $0.447 \pm 0.0005$ & $3.37 \pm 0.02^{b}$ & $583.33 \pm 2.85^{a b c}$ \\
\hline Formula 2 & $42.38 \pm 0.72^{c}$ & $35.78 \pm 2.45$ & $0.435 \pm 0.0115$ & $3.43 \pm 0.01^{a}$ & $586.00 \pm 2.52^{a b}$ \\
\hline Formula 3 & $47.94 \pm 1.94^{\mathrm{b}}$ & $37.75 \pm 1.52$ & $0.434 \pm 0.0113$ & $3.40 \pm 0.01^{\mathrm{ab}}$ & $582.33 \pm 1.20^{b c}$ \\
\hline Formula 4 & $46.18 \pm 1.68^{b c}$ & $35.92 \pm 4.32$ & $0.454 \pm 0.0105$ & $3.42 \pm 0.01^{\mathrm{ab}}$ & $590.33 \pm 6.39 a b$ \\
\hline Formula 5 & $54.74 \pm 1.69^{\mathrm{a}}$ & $39.47 \pm 1.08$ & $0.453 \pm 0.0086$ & $3.40 \pm 0.02^{\mathrm{ab}}$ & $583.33 \pm 2.91^{\mathrm{abc}}$ \\
\hline Formula 6 & $55.90 \pm 0.73^{a}$ & $41.78 \pm 1.93$ & $0.489 \pm 0.0095$ & $3.45 \pm 0.01^{\mathrm{a}}$ & $593.67 \pm 1.20^{a}$ \\
\hline ANOVA & $* *$ & NS & NS & $* *$ & $* *$ \\
\hline
\end{tabular}

Means \pm standard errors within a column followed by the same superscript letter(s) are not significantly different according to the Duncan's multiple range test. NS: non-significant differences, ${ }^{* *} p<0.01$.

\section{Conclusions}

Our results show that the application of bio-products containing a combination of rhizosphere and endophytic bacteria with antifungal and plant growth promoting activities can increase health and yield of black pepper. In our experiment, less Phytopthora and Fusarium was detected in soil and on roots after application of bio-products. Moreover, several of our treatments significantly reduced yellowing symptoms and increased the yield. Thus the bio-products contaning rhizosphere bacteria and endophytic bacteria are promising candidates to support sustainable and efficient black pepper production by minimizing the use of fungicides and chemical fertilizers. As this investigation was limited to selected farms in the Central Highlands of Vietnam, further studies at other black pepper growing locations at lager scales are recommended for an extensive evaluation of the performance of the bio-products reported here.

Author Contributions: S.D.N.; A.D.N.; T.D.T.: conceptualization and trial design; T.H.T.T., V.A.N.: Data analysis; H.V.C.; T.V.N., A.D.N.: Writing and Editing. All authors have read and agreed to the published version of the manuscript.

Funding: This research was funded by Science and Technology Program of the Ministry of Education and Training, Vietnam; Grant number B 2018-2020.

Institutional Review Board Statement: Not applicable.

Informed Consent Statement: Not applicable.

Data Availability Statement: Data available in a publicly accessible repository.

Acknowledgments: This work was supported by grants from the Science and Technology program of the Ministry of Education and Training, Vietnam: "Application of Biotechnology for sustainable black pepper production in the Central Highland". B 2018-2020.

Conflicts of Interest: The authors declare no conflict of interest.

\section{References}

1. Krishnamoorthy, B.; Parthasarathy, V.A. Review: Improvement of black pepper. CAB Rev. 2010, 5, 1-12. [CrossRef]

2. Acharya, S.G.; Momin, A.H.; Gajjar, A.V. Review of piperine as a bio-enhancer. Am. J. Pharm. Tech. Res. 2012, 2, 32-44.

3. Ahmad, N.; Fazal, H.; Abbasi, B.H.; Farooq, S.; Ali, M.; Khan, M.A. Biological role of Piper nigrum L. (black pepper): A review. Asian Pac. J. Trop. Biomed. 2012, 3, 1945-1953. [CrossRef]

4. Vietnam Pepper Association (VPA). Report; VPA: Ho Chi Minh, Vietnam, 2020.

5. Kueh, T.K.; Sim, S.L. Slow decline of black pepper caused by root knot nematodes. In The International Workshop on Black Pepper Diseases; Wahid, P., Sitepu, D., Deciyanto, S., Superman, U., Eds.; Bander Lampung Indonesia Institute for Spices and Medicinal Crops: Bogor, Indonesia, 1992; pp. 198-207.

6. Anandaraj, M.; Ramana, K.V.; Sarma, Y.R. Role of Phytophthora capsici in the slow decline disease of black pepper. J. Plantn. Crops 1996, 24, 166-170. 
7. Trudgill, D.L.; Blok, V.C. Apomictic, polyphagous root-knot nematodes: Exceptionally successful and damaging biotrophic root pathogens. Annu. Rev. Phytopathol. 2001, 39, 53-77. [CrossRef]

8. Aravind, R.; Kumar, A.; Eapen, S.J.; Ramana, K.V. Endobacterial flora in root and stem tissues of black pepper (Piper nigrum L.) genotype: Isolation, identification and evaluation against Phytophthora capsici. Lett. Appl. Microbiol. 2009, 48, 58-64. [CrossRef]

9. Trinh, T.H.T.; Wang, S.L.; Nguyen, V.B.; Tran, M.D.; Doan, C.T.; Vo, T.P.K.; Huynh, V.Q.; Nguyen, A.D. A potent antifungal rhizobacteria Bacillus velezensis RB.DS29 isolated from black pepper (Piper nigrum L.). Res. Chem. Intermed. 2019, 45, 5309-5323. [CrossRef]

10. Anith, K.N.; Radhakrishnan, N.V.; Manomohandas, T.P. Screening of antagonistic bacteria for biological control of nursery wilt of black pepper (Piper nigrum). Microbiol. Res. 2003, 158, 91-97. [CrossRef]

11. Trivedi, P.C. Bacteria in Agrobiology: Disease Management; Maheshwari, D.K., Ed.; Springer: Berlin, Germany, $2013 ;$ p. 349.

12. Ney, L.; Franklin, D.; Mahmud, K.; Cabrera, M.; Hancock, D.; Habteselassie, M.; Newcomer, Q.; Dahal, S.; Subedi, A. Sensitivity of Nematode Community Analysis to Agricultural Management Practices and Inoculation with Local Effective Microorganisms in the Southeastern United States. Soil Syst. 2019, 3, 41. [CrossRef]

13. Ney, L.; Franklin, D.; Mahmud, K.; Cabrera, M.; Hancock, D.; Habteselassie, M.; Newcomer, Q.; Dahal, S. Impact of Inoculation with Local Effective Microorganisms on Soil Nitrogen Cycling and Legume Productivity Using Composted Broiler Litter. Appl. Soil Ecol. 2020, 154, 103567. [CrossRef]

14. Ammar, M.; Hamad, M.; Hussien, S.; Mahmmoud, E.N. The Inhibitory Role of Effective Microorganisms (Em) on the Growth of Pathogenic Bacteria. Iraqi J. Vet. Sci 2020, 34, 153-158.

15. Bahuguna, A.; Joe, A.-R.; Kumar, V.; Lee, J.S.; Kim, S.-Y.; Moon, J.-Y.; Cho, S.-K.; Cho, H.; Kim, M. Study on the Identification Methods for Effective Microorganisms in Commercially Available Organic Agriculture Materials. Microorganisms 2020, 8, 1568. [CrossRef] [PubMed]

16. Anderson, R.C. Nematode Parasites of Vertebrates: Their Development and Transmission, 2nd ed.; CABI: Wallingford, UK, 2000; pp. 1-2. ISBN 9780851994215.

17. Sikora, R.A.; Fernández, E. Nematode parasites of vegetables. In Plant Parasitic Nematodes in Subtropical and Tropical Agriculture, 2nd ed.; Luc, M., Sikora, R.A., Bridge, J., Eds.; CABI Publishing: Wallingford, UK, 2005; pp. 319-376.

18. Nair, K.P.P. The Agronomy and Economy of Turmeric and Ginger; Elsevier: Amsterdam, The Netherlands, 2013 ; pp. $139-157$.

19. Wiratno, M.S.; Ankardiansyah, P.P.; Ahmed, I.A.Y. Biological control of root-knot nematode (meloidogyne spp.) in pepper plants utilizing endophytic bacteria Pseudomona ssp. Micrococcussp. J. Pepper Ind. 2018, 9, 11-22.

20. Nguyen, V.N.; Oh, I.J.; Kim, Y.J.; Kim, K.Y.; Kim, Y.C.; Park, R.D. Purification and characterization of chitinases from Paecilomyces variotii DG-3 parasitizing on Meloidogyne incognita eggs. J. Ind. Microbiol. Biotechnol. 2009, 36, 195-203. [CrossRef]

21. Vicente, P.C.; Renata, S.C.D.P.; Eduardo, S.F. Volatiles produced by interacting microorganisms potentially useful for the control of plant pathogens. Ciênc. Agrotecnol. Lavras. 2010, 34, 525-535.

22. Abdelnabby, H.M.; Mohamed, H.A.; AboAly, H.E. Nematode-antagonistic compounds from certain bacterial species. Egypt. J. Biol. Pest Control 2011, 21, 209-217.

23. Gao, H.; Qi, G.; Yin, R.; Zhang, H.; Li, C.; Zhao, X. Bacillus cereus strain S2 shows high nematicidal activity against Meloidogyne incognita by producing sphingosine. Sci. Rep. 2016, 24, 28756.

24. Beneduzi, A.; Ambrosini, A.; Passaglia, L.M. Plant growth-promoting rhizobacteria (PGPR): Their potential as antagonists and biocontrol agents. Genet. Mol. Biol. 2012, 35, 1044-1051. [CrossRef]

25. Elhady, A.; Giné, A.; Topalovic, O.; Jacquiod, S.; Sørensen, S.J.; Sorribas, F.J.; Heuer, H. Microbiomes associated with infective stages of root-knot and lesion nematodes in soil. PLoS ONE 2017, 12, e0177145. [CrossRef]

26. Basyony, A.G.; Abo-Zaid, G.A. Biocontrol of the root-knot nematode, Meloidogyne incognita, using an eco-friendly formulation from Bacillus subtilis, lab. and greenhouse studies. Egypt. J. Biol. Pest Control 2018, 28, 87. [CrossRef]

27. Tran, T.P.H.; Wang, S.-L.; Nguyen, V.B.; Tran, D.M.; Nguyen, D.S.; Nguyen, A.D. Study of Novel Endophytic Bacteria for Biocontrol of Black Pepper Root-knot Nematodes in the Central Highlands of Vietnam. Agronomy 2019, 9, 714. [CrossRef]

28. Nguyen, A.D.; Wang, S.L.; Trinh, T.H.T.; Tran, T.N.; Nguyen, V.B.; Doan, C.T.; Huynh, V.Q.; Vo, T.P.K. Plant growth promotion and fungal antagonism of endophytic bacteria for the sustainable production of black pepper (Piper nigrum L.). Res. Chem. Intermed. 2019, 45, 5325-5339. [CrossRef]

29. Nguyen, V.L. Spread of Phytophthora capsici in Black Pepper (Piper nigrum) in Vietnam. Engineering 2015, 7, 506-513. [CrossRef]

30. Toh, S.C.; Samuel, L.; Awang, A.S.A.H. Screening for antifungal- producing bacteria from Piper nigrum plant against Phytopthora capsici. Int. Food Res. J. 2016, 23, 2616-2622.

31. Partelli, F.L. Nutrient of black pepper: A Brasilian experience. J. Spice Aromat. Crops 2009, 18, $73-83$.

32. Dinesh, R.; Srinivasan, V.; Hamza, S.; Parthasarathy, V.A.; Aipe, K.C. Physico-chemical, biochemical and microbial properties of the rhizospheric soils of tree species used as supports for black pepper cultivation in the humid tropics. Geoderma 2010, 158, 252-258. [CrossRef]

33. Sheoran, N.; Nadakkakath, A.V.; Munjal, V.; Kundu, A.; Subaharan, K.; Venugopal, V.; Rajamma, S.; Eapen, S.J.; Kumar, A. Genetic analysis of plant endophytic Pseudomonas putida BP25 and chemo-profiling of its antimicrobial volatile organic compounds. Microbiol. Res. 2015, 173, 66-78. [CrossRef]

34. Jasim, B.; Jimtha, C.J.; Jyothis, M.; Radhakrishnan, E.K. Plant growth promoting potential of endophytic bacteria isolated from Piper nigrum. Plant Growth Regul. 2013, 71, 1-11. [CrossRef] 
35. Munjal, V.; Nadakkakath, V.A.; Sheoran, N.; Kundu, A.; Venugopal, V.; Subaharan, K.; Rajamma, S.; Eapen, S.J.; Kumar, A. Genotyping and identification of broad spectrum antimicrobial volatiles in black pepper root endophytic biocontrol agent, Bacillus megaterium BP17. Biol. Control. 2016, 92, 66-76. [CrossRef]

36. Ngo, V.A.; Wang, S.-L.; Nguyen, V.B.; Doan, C.T.; Tran, T.N.; Tran, D.M.; Nguyen, A.D. Phytophthora Antagonism of Endophytic Bacteria Isolated from Roots of Black Pepper (Piper nigrum L.). Agronomy 2020, 10, 286. [CrossRef]

37. Ogunmwonyi, I.N.; Igbinosa, O.E.; Aiyegoro, O.A.; Odjadjare, E.E. Microbial analysis of different top soil samples of selected site in Obafemi Awolowo University, Nigeria. Sci. Res. Essay 2008, 3, 120-124.

38. Maren, A.K. Identification of common Paenibacillus polymyxa and Bacillus Aspergillus species. In Pulished by the Pumilus Strains from Barley Rhizosphere; Central Bureau Voor Schimmelcutues, FEMS Microbiology Ecology: Utrecht, The Nethrlands, 2002 ; p. 107.

39. Henderson, C.F.; Tilton, E.W. Tests with acaricides against the brow wheat mite. J. Econ. Entomol. 1955, 48, 157-161. [CrossRef]

40. Rajalakshmi, K. Extraction and Estimation of Chlorophyll from Medicinal Plants. Int. J. Sci. Res. 2015, 4, $209-212$.

41. Getman-Pickering, Z.L.; Campbell, A.; Aflitto, N.; Grele, A.; Davis, J.K.; Ugine, T.A. LeafByte: A mobile application that measures leaf area and herbivory quickly and accurately. Methods Ecol. Evol. 2020, 11, 215-221. Available online: https://zoegp.science/ leafbyte (accessed on 26 December 2020). [CrossRef]

42. Olanrewaju, S.O.; Bernard, R.; Glick, B.R.; Babalola, O.O. Review: Mechanisms of action of plant growth promoting bacteria. World J. Microbiol. Biotechnol. 2017, 33, 197. [CrossRef]

43. Jacoby, R.; Peukert, M.; Succurro, A.; Koprivova, A.; Kopriva, S. The Role of Soil Microorganisms in Plant Mineral NutritionCurrent Knowledge and Future Directions. Front. Plant Sci. 2017, 8, 1617. [CrossRef]

44. Lim, S.M.; Yoon, M.-Y.; Choi, G.J.; Choi, Y.H.; Jang, K.S.; Shin, T.S.; Park, H.W.; Yu, N.H.; Kim, Y.H.; Kim, J.-C. Diffusible and Volatile Antifungal Compounds Produced by an Antagonistic Bacillus Velezensis G341 against Various Phytopathogenic Fungi. Plant Pathol. J. 2017, 33, 488-498. [CrossRef]

45. Palazzini, J.M.; Christopher, A.D.; Michael, J.B.; Sofía, N.C. Bacillus Velezensis Rc 218 as a Biocontrol Agent to Reduce Fusarium Head Blight and Deoxynivalenol Accumulation: Genome Sequencing and Secondary Metabolite Cluster Profiles. Microbiol. Res. 2016, 192, 30-36. [CrossRef]

46. Cai, X.-C.; Liu, C.-H.; Wang, B.-T.; Xue, Y.-R. Genomic and Metabolic Traits Endow Bacillus Velezensis Cc09 with a Potential Biocontrol Agent in Control of Wheat Powdery Mildew Disease. Microbiol. Res. 2016, 196, 89-94. [CrossRef]

47. Nguyen, T.H.; Nguyen, A.D.; Nguyen, Q.V. Biodiversity of Soil Microorganisms and their Effects on Disease Management at Black Pepper Farms in Gia Lai Province. Asian J. Biol. 2020, 9, 1-11. [CrossRef]

48. Heimpel, G.E.; Mills, N. Biological Control—Ecology and Applications; Cambridge University Press: Cambridge, UK, 2017. [CrossRef]

49. Pieterse, C.M.J.; Zamioudis, C.; Berendsen, R.L.; Weller, D.M.; Van Wees, S.C.M.; Bakker, P.A.H.M. Induced systemic resistance by beneficial microbes. Annu. Rev. Phytopathol. 2014, 52, 347-375. [CrossRef] [PubMed]

50. Conrath, U.; Beckers, G.J.M.; Langenbach, C.J.G.; Jaskiewicz, M.R. Priming for enhanced defense. Annu. Rev. Phytopathol. 2015, 53, 97-119. [CrossRef] [PubMed]

51. Spadaro, D.; Droby, S. Development of biocontrol products for postharvest diseases of fruit: The importance of elucidating the mechanisms of action of yeast antagonists. Trends Food Sci. Technol. 2016, 47, 39-49. [CrossRef]

52. Ghorbanpour, M.; Omidvari, M.; Abbaszadeh-Dahaji, P.; Omidvar, R.; Kariman, K. Mechanisms underlying the protective effects of beneficial fungi against plant diseases. Biol. Control. 2018, 117, 147-157. [CrossRef]

53. Nguyen, T.C.Q.; Tran, V.H.; Nguyen, T.H.; Le, V.T.; Vu, T.H.; Pham, T.M.T.; Phung, Q.T. SH-BV1—A Bio-product controlling nematodes and root fungal disease of black pepper and coffee in Dak Nong, Gia Lai. In Proceedings of the Second National Conference on Plant Science, Rome, Italy, 21-23 September 2020; pp. 960-965.

54. Ann, Y.C. Rhizobacteria of Pepper (Piper Nigrum) and Their Antifungal Activities. Afr. J. Microbiol. Res. 2012, 19, 4185-4193.

55. Jamal, Q.; Lee, Y.S.; Jeon, H.; Park, Y.S.; Kim, K.Y. Isolation and Biocontrol Potential of Bacillus Amyloliquefaciens Y1 against Fungal Plant Pathogens. KJSSF 2015, 48, 485-491. [CrossRef]

56. Kröber, M.; Verwaaijen, B.; Wibberg, D.; Winkler, A.; Pühler, A.; Schlüter, A. Comparative Transcriptome Analysis of the Biocontrol Strain Bacillus Amyloliquefaciens Fzb42 as Response to Biofilm Formation Analyzed by Rna Sequencing. J. Biotechnol. 2016, 231, 212-223. [CrossRef]

57. Dastager, S.G.; Deepa, C.K.; Pandey, A. Potential Plant Growth-Promoting Activity of Serratia Nematodiphila Nii-0928 on Black Pepper (Piper Nigrum L.). World J. Microbiol. Biotechnol. 2011, 27, 259-265. [CrossRef]

58. Samaniego-Gámez, B.; Garruña, R.; Tun-Suárez, J.; Kantun-Can, J.; Reyes-Ramírez, A.; Cervantes-Díaz, L. Bacillus spp. Inoculation Improves Photosystem Ii Efficiency and Enhances Photosynthesis in Pepper Plants. Chil. J. Agric. Res. 2016, 76, 409-416. [CrossRef] 